\title{
Isolation and identification of a novel protein elicitor from a Bacillus subtilis strain BU412
}

\author{
Yongrui Shen ${ }^{\dagger}$, Jianwei Li, Junliang Xiang, Jiaqi Wang, Kuide Yin and Quan Liu*†
}

\begin{abstract}
Here, we report a novel protein elicitor from Bacillus subtilis BU412 which could cause hypersensitive response (HR) and systemic acquired resistance (SAR) in tobacco. The purification was executed by ion-exchange and size exclusion chromatography. The target band on SDS-PAGE was analyzed by mass spectrometry, and the peptide mass fingerprinting matched an uncharacterized protein (WP_017418614.1), which was then named AMEP412. AMEP412 could cause a clearly defined HR necrosis in tobacco leaves, which was less affected by thermal treatment. The sub-cellular localization assay revealed that AMEP412 localized on the cell surface. This protein could also trigger early defense events such as the generation of reactive oxygen species $\left(\mathrm{H}_{2} \mathrm{O}_{2}\right.$ and $\left.\mathrm{O}_{2}{ }^{-}\right)$and the induction of defense enzymes, including superoxide dismutase (SOD), peroxidase (POD), polyphenol oxidase (PPO) and phenylalanine ammonialyase (PAL). Moreover, AMEP412 could stimulate plant systemic resistance against Pseudomonas syringae pv. tomato DC3000.
\end{abstract}

Keywords: Protein elicitor, Bacillus subtilis, Hypersensitive response, Reactive oxygen species, Induced systemic resistance

\section{Introduction}

During the long term interaction with pathogens, plants evolved different regulatory mechanisms to escape the attacks from pathogens (Díez-Navajas et al. 2008; Pieterse et al. 2009; Dodds and Rathjen 2010). Recognition of the pathogens or other foreign molecules is critical for the initiation of defence responses (Bruce and Pickett 2007). Elicitors, produced and released by microbes, are thought to have significant roles in signal exchange between plants and pathogens (Mishra et al. 2012).

Elicitors can induce plant defence responses, such as cell wall strengthening, reactive oxygen species (ROS), ethylene biosynthesis, expression of pathogenesis-related (PR) proteins, and induction of hypersensitive response (HR) (Wang et al. 2004; Miyata et al. 2006; Wang et al. 2012). These responses are first expressed in the infected area, which is called induced system resistance (ISR), and then extend to the non-infected area and create a

\footnotetext{
*Correspondence: 18765351@qq.com

${ }^{\dagger}$ Quan Liu and Yongrui Shen contributed equally to this work.

College of Life Science and Technology, Heilongjiang Bayi Agricultural University, Daqing 163319, China
}

systemic acquired resistance (SAR) (Yano et al. 1998; Durrant and Dong 2004; Garcia-Brugger et al. 2006).

Many protein elicitors have been isolated from a variety of pathogens, including Flagellin and Harpin from bacteria (Che et al. 2000; Wei et al. 1992), xylanase from fungi (Hanania and Avni 1997), invertase from yeast (Basse et al. 1993), and Elicitins from oomycetes (Ricci et al. 1989). However, several protein elicitors from biocontrol strains also have been reported to induce disease resistance, like Fengycins and Surfactins from Bacillus subtilis (Ongena et al. 2007), PeBA1 from Bacillus amyloliquefaciens (Wang et al. 2016) and BAR11 from Saccharothrix yanglingensis (Zhang et al. 2018).

In this paper, we reported the purification and characterization of a novel protein elicitor from a biocontrol strain Bacillus subtilis BU412. We performed a purification process that consisted of ion-exchange and size exclusion chromatography to gain the new protein elicitor, and identified it by mass spectrometry. Plant defence response caused by the new protein elicitor was determined, like HR, ROS burst, induction of defense enzymes, and SAR against infection by Pseudomonas syringae pv. tomato DC3000. 


\section{Materials and methods}

\section{Plants, strains, and growth conditions}

Nicotiana tabacum was grown at $24-26{ }^{\circ} \mathrm{C}$, with a $12-\mathrm{h}$ light/dark in a phytotron. Bacillus subtilis BU412 was isolated from potato field by our laboratory and deposited in China Center for Type Culture Collection (CCTCC M2016142). YME medium (Schaad et al. 2001) was used to culture the strain. Pseudomonas syringae pv. tomato (Pst) DC3000 (ATCC BAA-871) was cultured in low salt LB (half dosage of $\mathrm{NaCl}$ ) medium containing $50 \mathrm{mg} \mathrm{L}^{-1}$ rifampicin at $28{ }^{\circ} \mathrm{C}$ overnight as previously described (Katagiri et al. 2002). Culture cells were harvested and the final concentration of cell suspensions was adjusted to $5 \times 10^{5} \mathrm{cfu} \mathrm{mL}{ }^{-1}$ using $20 \mathrm{mM}$ Tris- $\mathrm{HCl}(\mathrm{pH} 7.5)$.

\section{Protein purification}

A single colony of Bacillus subtilis BU412 was cultured in YME liquid medium at $32{ }^{\circ} \mathrm{C}$ and $160 \mathrm{rpm}$ for $12 \mathrm{~h}$ as seed liquid. $3 \mathrm{~mL}$ seed liquid was inoculated into $300 \mathrm{~mL}$ YME liquid medium and cultured at $32{ }^{\circ} \mathrm{C}, 160 \mathrm{rpm}$ for $22 \mathrm{~h}$. The supernatant was collected by centrifugation at $4{ }^{\circ} \mathrm{C}, 16,000 \times g$ for $30 \mathrm{~min}$.

The culture supernatant was filtered through $0.22 \mu \mathrm{m}$ membrane and applied to a Source 15Q 4.6/100 PE column, on an AKTA Purifier system (Amersham Biosciences) pre-equilibrated with $20 \mathrm{mM}$ Tris- $\mathrm{HCl}(\mathrm{pH}$ 7.5). The column was washed with a linear gradient of $0.5 \mathrm{M} \mathrm{NaCl}$ from 0 to $100 \%$ concentration in $20 \mathrm{mM}$

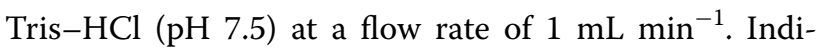
vidual peak fractions were concentrated to $1 \mathrm{mg} \mathrm{mL}^{-1}$ by Amicon ultra centrifugal filters (Millipore) and tested for HR activity on tobacco leaves. Protein samples with HR activity were applied to a Superdex 75 10/300 GL column. The column was eluted with $20 \mathrm{mM}$ Tris $-\mathrm{HCl}$

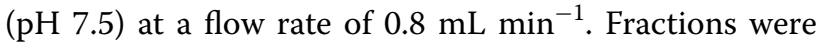
collected and tested for HR activity, and then determined by SDS-PAGE. All purification steps were performed at room temperature, and the column effluent was monitored by absorbance at $280 \mathrm{~nm}$.

\section{Mass spectrum analysis}

The exclusive protein band in SDS-PAGE gel was removed, gel-digested and analyzed with 4700 MALDITOF/TOF mass spectrometer (AB SCIEX). Strong mother ions were selected to get second mass spectrum (MS/MS). The peptide mass fingerprinting (PMF) of MS and MS/MS was searched with Mascot (Matrix Sciences) search engine to identify the protein.

\section{Characterization of the elicitor}

Protein elicitor samples used in the following assays were purified from the supernatant of BU412 culture through ion-exchange and size exclusion chromatography following the methods mentioned above. All protein concentrations were measured using NanoDrop One UV Spectrophotometer (Thermo Scientific).

\section{$H R$ and Trypan blue staining}

In order to check the effect of the new protein elicitor for the HR-inducing activity in tobacco, $1 \mathrm{mg} \mathrm{mL}^{-1}$ protein elicitor was infiltrated into the leaves using a syringe without needle to cover areas of $1 \mathrm{~cm}^{2}$. The HR symptom necrosis was examined in the injected areas after $24 \mathrm{~h}$. Tobacco leaves with HR were stained by Trypan blue and then observed under a microscope, according to the previously described method (Koch and Slusarenko 1990).

\section{The minimum concentration for HR induction}

In order to check the minimum concentration of the new protein elicitor for the induction of $\mathrm{HR}$ in tobacco, different concentrations of protein elicitor $(2.4,2.0,1.6,1.2$, 0.8 and $0.4 \mathrm{mg} \mathrm{mL}^{-1}$ ) in a $100-\mu \mathrm{L}$ volume were infiltrated into tobacco leaves using a $1 \mathrm{~mL}$ needleless syringe, with $20 \mathrm{mM}$ Tris- $\mathrm{HCl}$ (pH 7.5) as control. HR symptoms were examined after $24 \mathrm{~h}$.

\section{The thermo stability test of the protein elicitor}

To test the thermo stability, protein elicitor was treated at different temperatures $\left(25,40,60,80\right.$, and $\left.100{ }^{\circ} \mathrm{C}\right)$ for $5 \mathrm{~min}$ and then infiltrated into tobacco leaves after cooling to room temperature. The HR responses for infiltrated tobacco leaves were observed after $24 \mathrm{~h}$.

\section{Sub-cellular localization}

Two milligrams of the protein elicitor was reacted with $0.1 \mathrm{mg}$ of FITC in $2 \mathrm{~mL}$ of carbonate buffer $(0.05 \mathrm{M}, \mathrm{pH}$ 9.0) for $12 \mathrm{~h}$ at $4{ }^{\circ} \mathrm{C}$. The FITC and protein elicitor mixture was applied to a Superdex 75 10/300 GL column equilibrated and eluted with $20 \mathrm{mM}$ Tris- $\mathrm{HCl}$ (pH 7.5). Thus, FITC-elicitor was separated from free FITC molecules. Subsequently, FITC-elicitor was infiltrated into the upper leaves of 6-week-old $N$. tabacum plants using a $1 \mathrm{~mL}$-syringe without needle. The leaves were shredded at $4 \mathrm{~h}$ post injection, and a laser confocal microscope (Leica SP8) with an excitation wavelength of $495 \mathrm{~nm}$ was then used to observe the localization.

\section{ROS accumulation}

One of the early events during the HR is the generation of reactive oxygen as an active process to signal downstream cellular processes (Torres et al. 2006). Accumulation of hydrogen peroxide was detected by a peroxidasedependent in situ histochemical staining procedure using 3,3-diaminobenzidine (DAB) (Thordal-Christensen et al. 1997) and superoxide ion using a superoxidedependent reduction of nitro blue tetrazolium (NBT) 

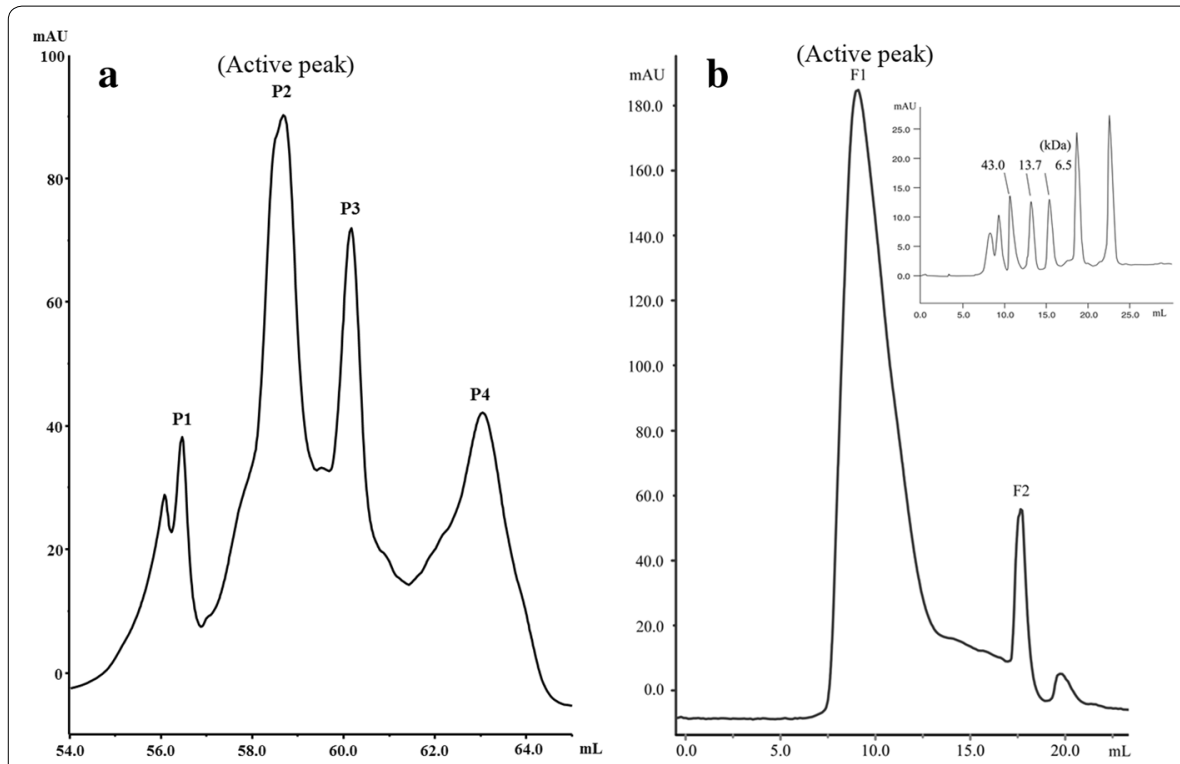

C

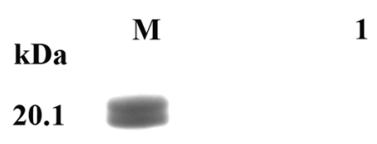

14.4

7.8

5.8

3.3

Fig. 1 The purification of the new elicitor protein. a The anion exchange chromatography map. P1-P4 were peaks eluted with a linear gradient of $\mathrm{NaCl}$. b The superdex chromatography map. F1 and F2 were peaks eluted with $20 \mathrm{mM} \mathrm{Tris-HCl}$. Inset, typical chromatogram from a function test of Superdex 75 10/300 GL (Amersham Biosciences). c The SDS-PAGE detection of the target protein. M: low molecular weight standards, 1: the purified protein sample of the peak F2, B1: the target protein band

a

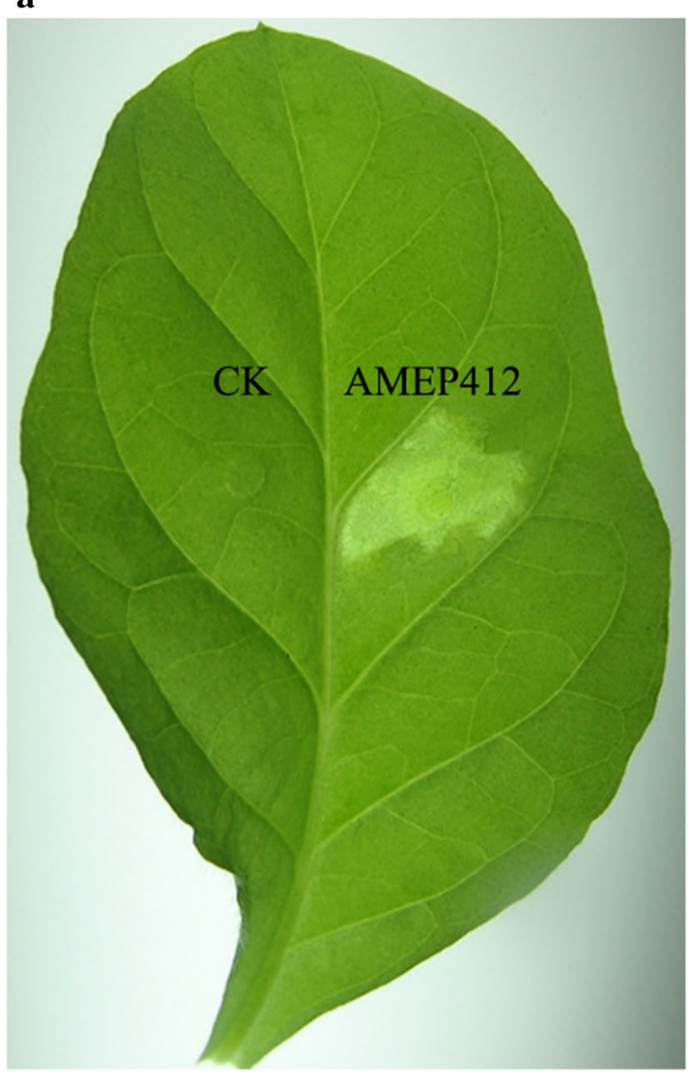

b

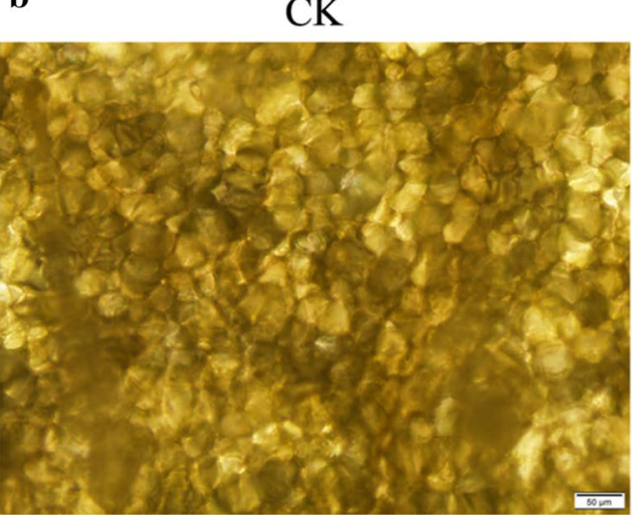

AMEP412

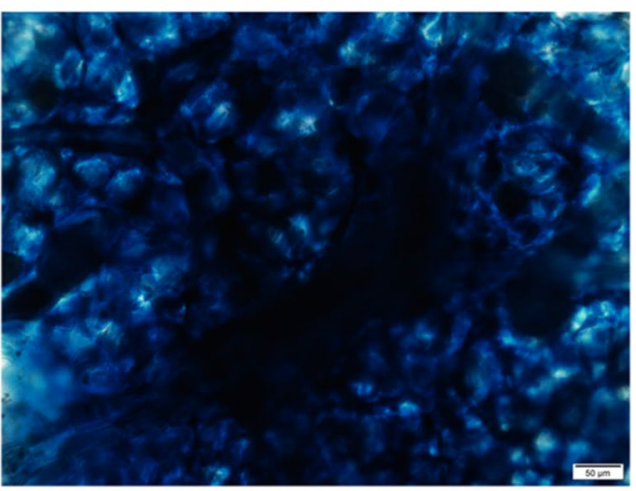

Fig. 2 AMEP412 induced HR in tobacco leaves. a HR lesion caused by AMEP412 in tobacco leaves. b Trypan blue staining of the HR areas infiltrated by AMEP412. Buffer treatment areas could not be stained by dye. AMEP412 induced cell death in infiltrated areas was stained blue. Scale bar $=50 \mu m$ 
(Doke 1983). Leaves of $N$. tabacum plants were sprayed with $50 \mu \mathrm{g} \mathrm{mL} \mathrm{m}^{-1}$ AMEP412, and buffers were used as control. At different post treatment hours $(0,4,12$, and $24 \mathrm{~h}$ ), leaves were cut and then vacuum-infiltrated with $1 \mathrm{mg} \mathrm{mL}{ }^{-1}$ DAB (pH 3.8) or $1 \mathrm{mg} \mathrm{mL}^{-1} \mathrm{NBT}$ for $2 \mathrm{~h}$. The treated leaves were incubated for more than $24 \mathrm{~h}$ in $70 \%$ ethanol and 5\% glycerol to eliminate chlorophyll, observed for DAB and NBT deposits, and photographed.

\section{Induction of defense enzymes}

Leaves of $N$. tabacum plants were sprayed with $50 \mu \mathrm{g} \mathrm{mL}^{-1}$ AMEP412, and buffers were used as control. Leaves were harvested at different times $(0,4,8,12$, 24,48 , and $72 \mathrm{~h}$ ) after treatment and immediately frozen in liquid nitrogen. Then, samples of each treatment were homogenized in extraction buffer $(50 \mathrm{mM}$ phosphate buffer, $\mathrm{pH} 7.8$ ) using mortar and pestle. The lysate was then centrifuged at $16,000 \times g$ for $20 \mathrm{~min}$ at $4{ }^{\circ} \mathrm{C}$. The supernatant was collected for use as crude enzyme extracts. The activities of SOD, POD, PPO and PAL were assayed according to the previously described method (Hano et al. 2008).

\section{Induced disease resistance in tobacco}

Six-week-old N. tabacum plants were used for the following assay. Two leaves of tobacco plant were treated with protein elicitor $\left(50 \mu \mathrm{g} \mathrm{mL}^{-1}\right)$ by spraying, using buffer as control. At $24 \mathrm{~h}$ post treatment, $50 \mu \mathrm{L}$ Pst DC3000 cell

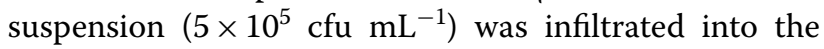
untreated systemic leaves using a $1 \mathrm{~mL}$-syringe without needle. Inoculated plants were maintained in growth chamber at $22{ }^{\circ} \mathrm{C}$ with high humidity and a 16-h day/8-h night cycle. Symptoms were observed 4 days post infection with Pst DC3000.

\section{Results}

\section{Purification and identification of the new protein elicitor}

The supernatant was prepared through centrifugation and filtration, which was then applied for anion exchange purification. The anion exchange chromatography obtained four main peaks after a linear gradient elution (Fig. 1a), and the peak P2 showed HR activity. Then P2 was concentrated and further purified by Superdex column, and two main peaks were collected (Fig. 1b). The peak $\mathrm{F} 1$ had $\mathrm{HR}$ activity and showed a main megascopic band (B1) around $7 \mathrm{kDa}$ on SDS-PAGE (Fig. 1c), which was thought to be the target protein.

Band B1 was cut off and analyzed by Maldi-TOF mass spectrometer and the mass spectrum was shown in Additional file 1: Figure S1. Mascot search results indicated that peptide mass fingerprinting (PMF) of the sequenced protein had the best similarity to an uncharacterized protein (WP_017418614.1). The amino acid sequence was shown in Additional file 1: Figure S2 with bold and italic letters indicating the matched amino acids with the sequenced protein. There were five amino acid fragments matched that included 37 amino acid residues and sequence coverage was $49 \%$. The above results allowed us to conclude that the protein identified in this study was most likely an uncharacterized protein, which was named AMEP412.

According to the analysis result of ProtParam (Wilkins et al. 1999), AMEP412 contained 76 amino acid residues with a relative molecular mass $(\mathrm{MW})$ of $8.36 \mathrm{kDa}$. In addition, the protein also consisted of $15.8 \%$ lysine, $13.2 \%$ alanine and $10.5 \%$ leucine. The protein had 2 negatively charged residues and 12 positively charged residues, and the isoelectric point (pI) reached 10.05. The instability index was computed to be 1.35 , which classified the protein as stable. A secondary structure prediction server (Drozdetskiy et al. 2015) analysis indicated that AMEP412 had five á-helices with no â-sheet and random coil (Additional file 1: Figure S2). The predicted results for the transmembrane domain (Tusnády and Simon 2001) showed that there was a transmembrane domain at position 17-36, which implied its binding ability with the membrane.

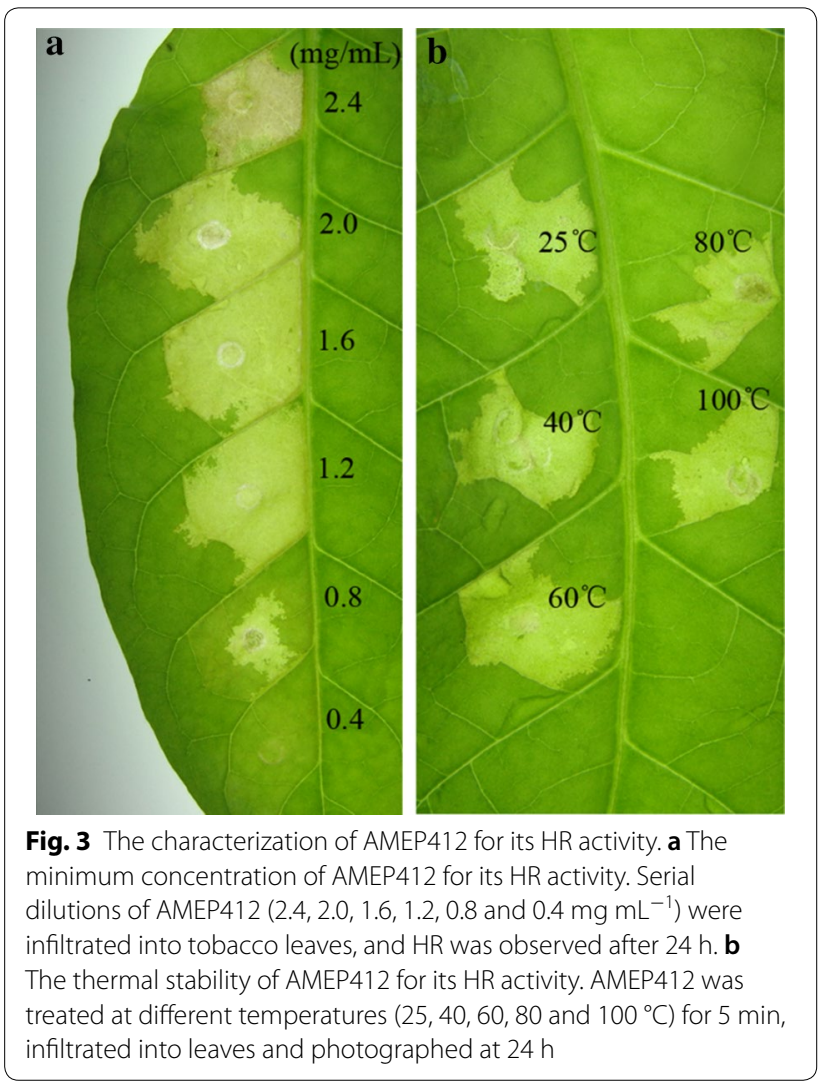



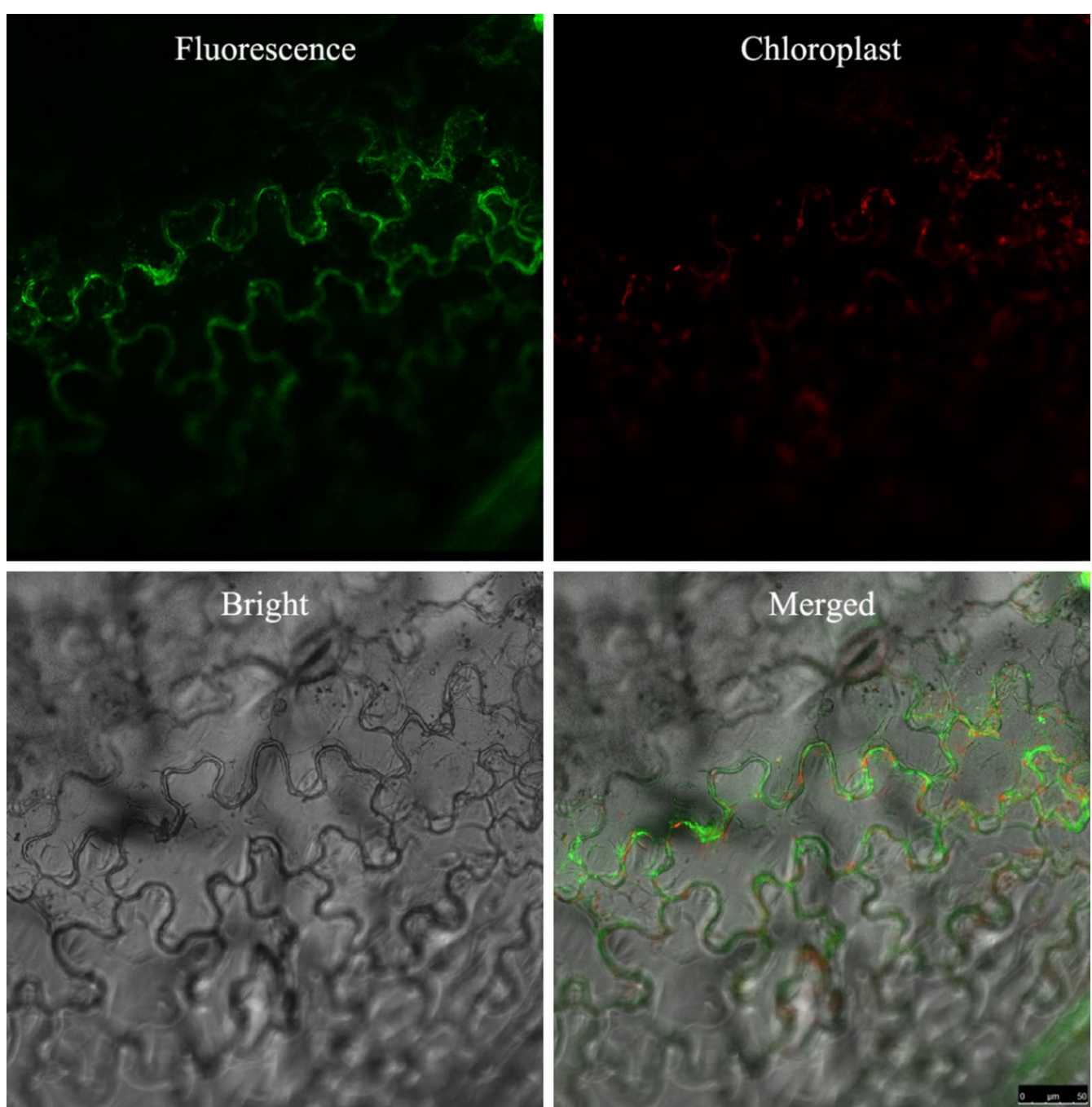

Fig. 4 Sub-cellular localization of AMEP412 in tobacco cells

\section{Characterization of AMEP412}

To confirm the HR activity of the new protein, $1 \mathrm{mg} \mathrm{mL}^{-1}$ AMEP412 was infiltrated into tobacco leaves, and clearly defined HR necrotic areas were found at the infiltration sites (Fig. 2a). HR is also a kind of cell death, which can be monitored by Trypan blue staining on the leaves. In our test, dead cells located at the site of HR were stained blue (Fig. 2b).

In order to check the minimum concentration needed for HR, serial dilutions of AMEP412 were infiltrated into tobacco leaves and the results showed that the minimum concentration was $0.8 \mathrm{mg} \mathrm{mL}^{-1}$ (Fig. 3a).

The thermo stability test showed that AMEP412 could induce obvious HR symptoms after treated at $25,40,60$, 80 and $100{ }^{\circ} \mathrm{C}$ for $5 \mathrm{~min}$, which suggested that AMEP412 had good thermal stability (Fig. 3b).

\section{Localization assay}

The cellular localization of AMEP412 was determined by generating a fusion with FITC. FITC-AMEP412 was infiltrated into tobacco leaves, and the fluorescent signals were observed using laser confocal microscope after $4 \mathrm{~h}$ incubation. As shown in Fig. 4, the fluorescence was observed to distribute almost uniformly along the cell wall and the cell peripheral surface. This result suggested that AMEP412 localized in the cell surface, which provided clues for the mechanism research.

\section{Induction of ROS production}

To further examine AMEP412 activated biochemical responses, the ROS accumulation were detected using DAB and NBT, respectively. As shown in Fig. 5, with the increase of treatment time, brown DAB-stained and 

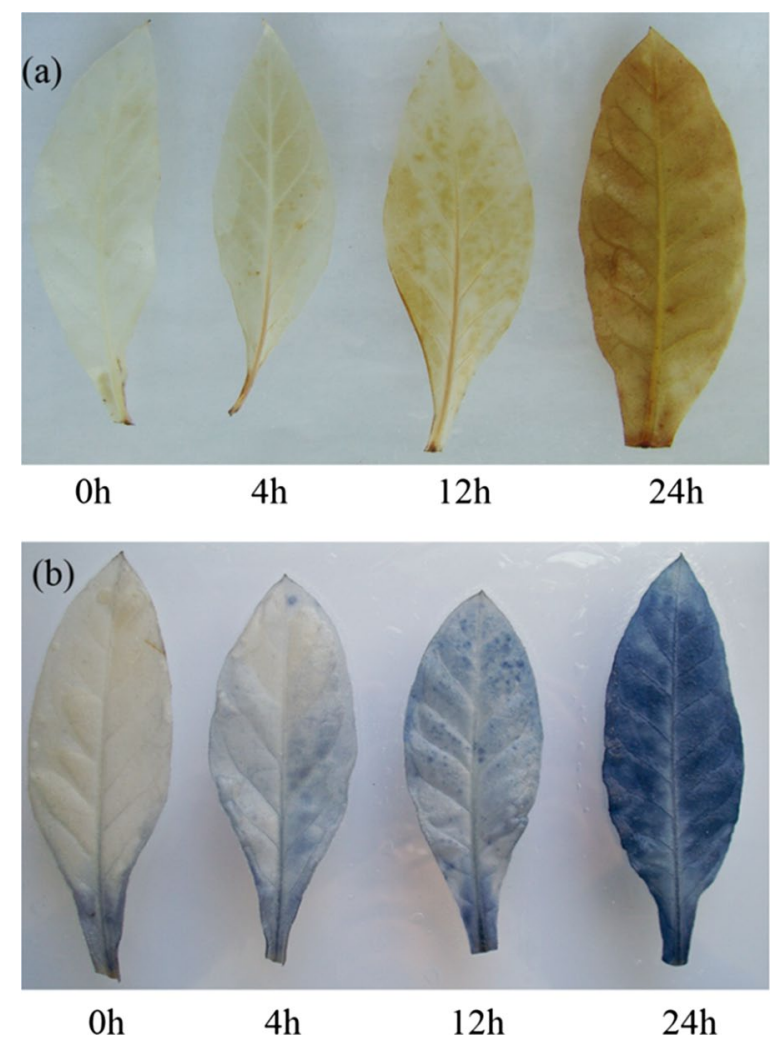

Fig. 5 Induction of ROS in tobacco leaves by AMEP412. a DAB showed the production of $\mathrm{H}_{2} \mathrm{O}_{2}$. The leaves were stained at different post treatment hours. $\mathrm{H}_{2} \mathrm{O}_{2}$ accumulation appeared in AMEP412 treated leaves. $\mathbf{b}$ NBT revealed the production of $\mathrm{O}_{2}{ }^{-}$, and staining was performed on leaves at the same treatment time. $\mathrm{O}_{2}{ }^{-}$ accumulation appeared in AMEP412 treated leaves

blue NBT-stained precipitates were increasing clearly observed. At $24 \mathrm{~h}$ post treatment, precipitates spread all over the tobacco leaves.

\section{Increase of defense enzymes in AMEP412 treated plants}

Defense related enzymes, including SOD, POD, PPO and PAL, were detected from 0 to $72 \mathrm{~h}$ after AMEP412 treatment. The activities of the above enzymes showed a similar trend, which appeared to be stimulated at $8 \mathrm{~h}$, peaked at $24 \mathrm{~h}$ after AMEP412 treatment and then gradually declined in the AMEP412 treated plants (Fig. 6).

\section{AMEP412 induced plant SAR}

The ability of AMEP412 to induce SAR of N. tabacum against Pst DC3000 was tested. The AMEP412 treatment significantly inhibited the lesion caused by Pst DC3000 in area and severity (Fig. 7), which suggested that AMEP412 could induce plant SAR.

\section{Discussion}

In this work, a novel protein elicitor AMEP412 was purified and characterized from Bacillus subtilis BU412. According to the BLAST result, AMEP412 was an uncharacterized protein without any function identified. It was reported widely distributed in genus Bacillus, including Bacillus velezensis, Bacillus amyloliquefaciens, Bacillus vallismortis, Bacillus subtilis, Bacillus vietnamensis, and Bacillus aquimaris. However, according to our research, the expression level of AMEP412 had an obvious dissimilarity between Bacillus strains (data not shown). It's worth mentioning that Bacillus subtilis BU412 had a high expression level of AMEP412, which not only facilitated its purification and identification, but also provided material for further assays.

Different with most other elicitors, AMEP412 is secreted by Bacillus subtilis, which is regarded as an ideal biocontrol strain. Its advantage lies in that it can secret various antimicrobial peptides (AMPs) in the fermentation process, such as Surfactin (Peypoux et al. 1999), Fengycin (Hu et al. 2007), Bacilysin (Rajavel et al. 2009), and Iturin (Arrebola et al. 2010). All the encoding genes of these AMPs were successfully detected by PCR amplification using BU412 as template (data not shown). Unlike eliciting plants' resistance against pathogens, these AMPs can directly inhibit plant pathogens. It will be a great enhancement for the disease control effect of AMEP412 applied products if these AMPs could be effectively saved during the fermentation and purification process.

AMEP412 contained 76 amino acid residues with a relative molecular mass of $8.36 \mathrm{kDa}$. However, according to the result of Superdex chromatography, the elution volume of AMEP412 (Fig. 1b, Peak F1) corresponded to a molecular weight of $>43 \mathrm{kDa}$, which was several times of its real molecular weight. This result indicated that AMEP412 probably formed polymers. The polymerization state could enhance its stability against thermal treatment, which explained why AMEP412 exhibited a good thermal stability.

HR is a form of cell death, which is regarded as part of plant innate immunity (Atkinson et al. 1990). Although some elicitors do not lead to HR symptoms (Mao et al. 2010; Zhang et al. 2010), HR is regarded as an important early event and widely used in elicitor screen and identification. In this study, high concentrations of AMEP412 could induce necrosis in tobacco leaves, and Trypan blue staining confirmed this result. Serial dilutions of AMEP412 were infiltrated into tobacco leaves for HR testing, and the minimum concentration of AMEP412 that inducing HR was $0.8 \mathrm{mg} \mathrm{mL}^{-1}$. 

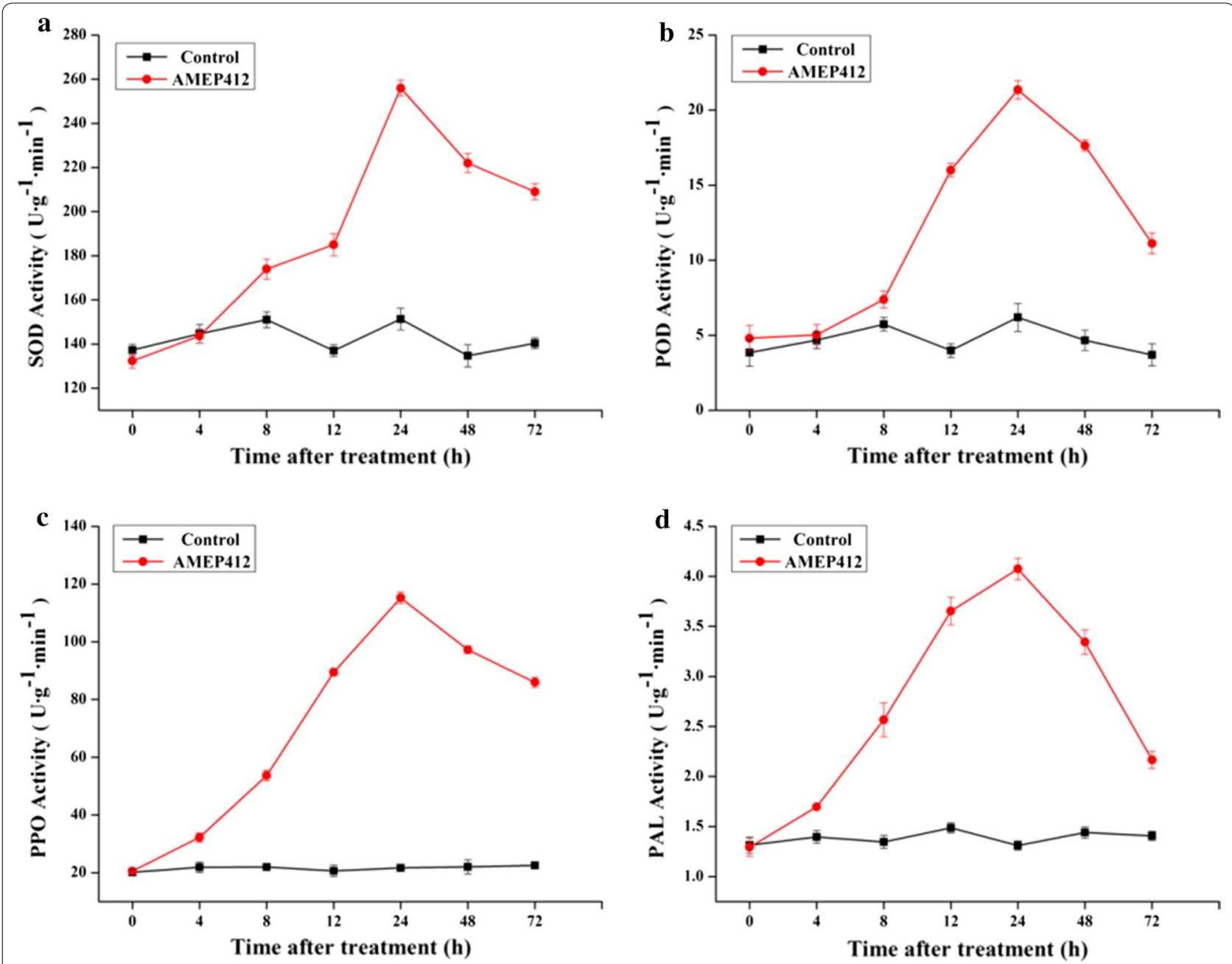

Fig. 6 Kinetics of SOD, POD, PPO and PAL activity after AMEP412 treatment. The activities were measured 0-72 h after AMEP412 treatment. The values are the mean $\pm S D$ of quintuplicate samples

Low concentrations of AMEP412 could not cause visible HR symptom. However, they could still interact with tobacco leaves and trigger a serials of defence responses, like ROS accumulation and expression of defense enzymes, which leaded to the activation of the plant immune system (Dangl and Jones 2001; Chisholm et al. 2006). In our research, all these defence responses occurred at about $24 \mathrm{~h}$ after treatment. However, some elicitors required more than 2 days to show the responses (Zhang et al. 2010; Bu et al. 2013; Wang et al. 2016). The reason of the difference probably lied in the diversified mechanisms, which deserved clarification in the following research. Considering the degradation problem of elicitors in application, fast induction of defence responses should be a non-negligible advantage for commercial product.
In this research, the new elicitor was observed to be localized on the surface of tobacco cell, which indicated that it did not need to enter the cell to exert its function. So, it was predicted there might be some receptors interacted with the new elicitor and then transducted the signal into the cell through a certain pathway. It has been verified that salicylic acid (SA) and jasmonic acid (JA) signal pathways are responsible for the elicitor triggered plant defence responses. SA is a key regulator of SAR, whereas JA is indispensable for ISR (Spoel and Dong 2008). Moreover, interactions have been reported between these two pathways, which can be either antagonistic or synergistic. However, the antagonistic interactions seem to be dominant (Yang et al. 2015). For AMEP412, more researches are needed to reveal the 

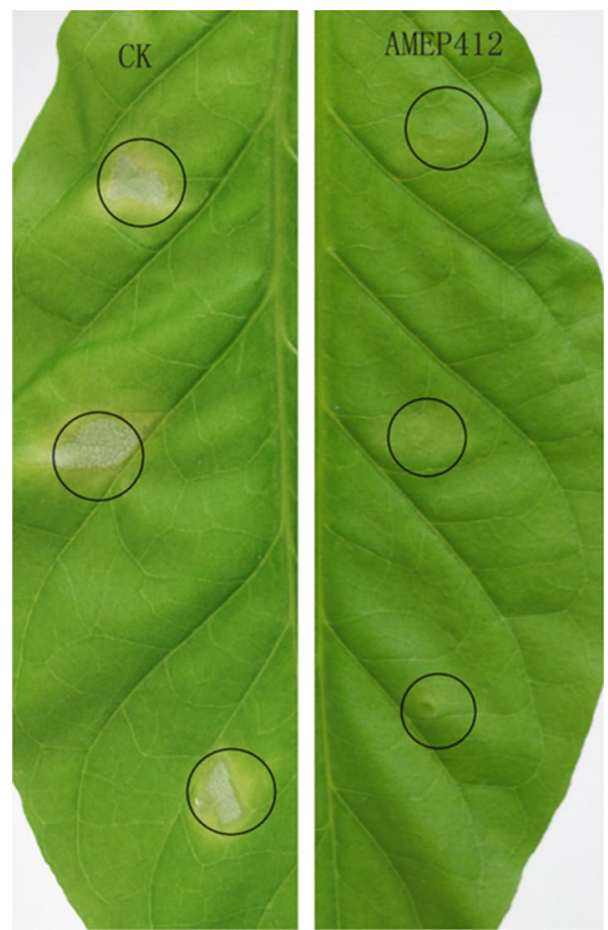

Fig. 7 AMEP412 induced systemic resistance in tobacco against Pst DC3000

receptor it interacts and the signal transduction pathway it utilizes.

In summary, our results showed that Bacillus subtilis BU412 produced a novel protein elicitor, AMEP412. It triggered a hypersensitive response in tobacco leaves and induced the production of signaling molecules and secondary metabolites related to plant resistance. Our results indicated that AMEP412 was a good plant defense activator and could be developed to a novel biopesticide in the future. In our next research, the fermentation conditions of BU412 will be optimized to increase the yield of AMEP412. Meanwhile, the exact mechanisms underlying AMEP412 induced priming of plant defence responses will also be studied.

\section{Additional file}

Additional file 1: Figure S1. The mass spectrometry of the target protein. Figure S2. Amino acid sequence information of AMEP412 (WP_017418614.1). Amino acid sequence of AMEP412 in the one letter code. A predicted secondary structure is given in the lower line. $H$, Alpha helix; $C$, random coiled. Bold and italic letters, the peptide fragments detected by MS sequencing. Underlined, the predicted transmembrane domain.

\section{Abbreviations}

HR: hypersensitive response; SAR: systemic acquired resistance; SOD: superoxide dismutase; POD: peroxidase; PPO: polyphenol oxidase; PAL: phenylalanine ammonia-lyase; ROS: reactive oxygen species; PR: pathogenesis-related; ISR: induced system resistance; SAR: systemic acquired resistance; PMF: peptide mass fingerprinting; DAB: 3,3-diaminobenzidine; NBT: nitro blue tetrazolium.

\section{Acknowledgements}

The authors thank Liwei Gu for manipulation of the laser confocal microscope. We also thank the reviewers, whose comments and suggestions helped us to improve this manuscript.

\section{Authors' contributions}

QL and YS (co-first author) were the primary contributors to this study with helpful advice from JL and JX and JW. QL (corresponding author) participated in design, draft and finalize the manuscript. KY helped for data analysis and revised the manuscript. All authors read and approved the final manuscript.

\section{Funding}

This work was financially supported by Natural Science Foundation of Heilongjiang Province of China (QC2017020) and Postdoctoral Science Foundation of Heilongjiang Bayi Agricultural University.

\section{Availability of data and materials}

Please turn to authors for all requests.

\section{Ethics approval and consent to participate}

Not applicable.

\section{Consent for publication}

All authors listed on this manuscript have read and agreed to the publication of this research.

\section{Competing interests}

The authors declare that they have no competing interests.

Received: 9 April 2019 Accepted: 24 June 2019

Published online: 27 July 2019

\section{References}

Arrebola $E$, Jacobs R, Korsten $L$ (2010) Iturin A is the principal inhibitor in the biocontrol activity of Bacillus amyloliquefaciens PPCB004 against postharvest fungal pathogens. J Appl Microbiol 108:386-395

Atkinson MM, Keppler LD, Orlandi EW, Baker CJ, Mischke CF (1990) Involvement of plasma membrane calcium influx in bacterial induction of the $\mathrm{K}^{+} / \mathrm{H}^{+}$and hypersensitive responses in tobacco. Plant Physiol 92:215-221

Basse CW, Fath A, Boller T (1993) High affinity binding of a glycopeptide elicitor to tomato cells and microsomal membranes and displacement by specific glycan suppressors. J Biol Chem 268:14724-14731

Bruce TJ, Pickett JA (2007) Plant defence signalling induced by biotic attacks. Curr Opin Plant Biol 10:387-392

Bu B, Qiu D, Zeng H, Guo L, Yuan J, Yang X (2013) A fungal protein elicitor PevD1 induces verticillium wilt resistance in cotton. Plant Cell Rep 33:461-470

Che FS, Nakajima Y, Tanaka N, Iwano M, Yoshida T, Takayama S, Kadota I, Isogai A (2000) Flagellin from an incompatible strain of Pseudomonas avenae induces a resistance response in cultured rice cells. J Biol Chem 275:32347-32356

Chisholm ST, Coaker G, Day B, Staskawicz BJ (2006) Host-microbe interactions: shaping the evolution of the plant immune response. Cell 124:803-814

Dangl JL, Jones JD (2001) Plant pathogens and integrated defence responses to infection. Nature 411:826-833

Díez-Navajas AM, Wiedemann-Merdinoglu S, Greif C, Merdinoglu D (2008) Nonhost versus host resistance to the grapevine downy mildew, Plasmopara viticola, studied at the tissue level. Phytopathology 98:776-780 
Dodds PN, Rathjen JP (2010) Plant immunity: towards an integrated view of plant-pathogen interactions. Nat Rev Genet 11:539-548

Doke N (1983) Generation of superoxide anion by potato tuber protoplasts during the hypersensitive response to hyphal wall components of Phytophthora infestans and specific inhibition of the reaction by suppressors of hypersensitivity. Physiol Plant Pathol 23:359-367

Drozdetskiy A, Cole C, Procter J, Barton GJ (2015) JPred4: a protein secondary structure prediction server. Nucleic Acids Res 43:W389-W394

Durrant WE, Dong X (2004) Systemic acquired resistance. Annu Rev Phytopathol 42:185-209

Garcia-Brugger A, Lamotte O, Vandelle E, Bourque S, Lecourieux D, Poinssot B, Wendehenne D, Pugin A (2006) Early signaling events induced by elicitors of plant defenses. Mol Plant Microbe Interact 19:711-724

Hanania U, Avni A (1997) High affinity binding site for ethylene-inducing xylanase elicitor on Nicotiana tabacum membranes. Plant J 12:113-120

Hano C, Addi M, Fliniaux O, Bensaddek L, Duverger E, Mesnard F, Lamblin F, Lainé $E$ (2008) Molecular characterization of cell death induced by a compatible interaction between Fusarium oxysporum f. sp. linii and flax (Linum usitatissimum) cells. Plant Physiol Biochem 46:590-600

Hu LB, Shi ZQ, Zhang T, Yang ZM (2007) Fengycin antibiotics isolated from B-FS01 culture inhibit the growth of Fusarium moniliforme Sheldon ATCC 38932. FEMS Microbiol Lett 272:91-98

Katagiri F, Thilmony R, He SY (2002) The Arabidopsis thaliana-Pseudomonas syringae interaction. Arabidopsis Book 1:e0039

Koch E, Slusarenko A (1990) Arabidopsis is susceptible to infection by a downy mildew fungus. Plant Cell 2:437-445

Mao J, Liu Q, Yang X, Long C, Zhao M, Zeng H, Liu H, Yuan J, Qiu D (2010) Purification and expression of a protein elicitor from Alternaria tenuissima and elicitor-mediated defence responses in tobacco. Ann Appl Biol 156:411-420

Mishra AK, Sharma K, Misra RS (2012) Elicitor recognition, signal transduction and induced resistance in plants. J Plant Interact 7:95-120

Miyata K, Miyashita M, Nose R, Otake Y, Miyagawa H (2006) Development of a colorimetric assay for determining the amount of $\mathrm{H}_{2} \mathrm{O}_{2}$ generated in tobacco cells in response to elicitors and its application to study of the structure-activity relationship of Flagellin-derived peptides. Biosci Biotechnol Biochem 70:2138-2144

Ongena M, Jourdan E, Adam A, Paquot M, Brans A, Joris B, Arpigny JL, Thonart $P$ (2007) Surfactin and Fengycin lipopeptides of Bacillus subtilis as elicitors of induced systemic resistance in plants. Environ Microbiol 9:1084-1090

Peypoux F, Bonmatin JM, Wallach J (1999) Recent trends in the biochemistry of Surfactin. Appl Microbiol Biotechnol 51:553-563

Pieterse CM, Leon-Reyes A, Van der ES, Van Wees SC (2009) Networking by small-molecule hormones in plant immunity. Nat Chem Biol 5:308-316

Rajavel M, Mitra A, Gopal B (2009) Role of Bacillus subtilis BacB in the synthesis of Bacilysin. J Biol Chem 284:31882-31892

Ricci P, Bonnet P, Huet JC, Sallantin M, Beauvais-Cante F, Bruneteau M, Billard $\checkmark$, Michel G, Pernollet JC (1989) Structure and activity of proteins from pathogenic fungi Phytophthora eliciting necrosis and acquired resistance in tobacco. Eur J Biochem 183:555-563
Schaad NW, Jones JB, Chun W (2001) Laboratory guide for the identification of plant pathogenic bacteria. The American Phyto-pathological Society, St. Paul

Spoel SH, Dong X (2008) Making sense of hormone crosstalk during plant immune responses. Cell Host Microbe 3:348-351

Thordal-Christensen H, Zhang Z, Wei Y, Collinge DB (1997) Subcellular localization of $\mathrm{H}_{2} \mathrm{O}_{2}$ in plants. $\mathrm{H}_{2} \mathrm{O}_{2}$ accumulation in papillae and hypersensitive response during the barley-powdery mildew interaction. Plant J 11:1187-1194

Torres MA, Jones JD, Dangl JL (2006) Reactive oxygen species signaling in response to pathogens. Plant Physiol 141:373-378

Tusnády GE, Simon I (2001) The HMMTOP transmembrane topology prediction server. Bioinformatics 17:849-850

Wang JY, Cai Y, Gou JY, Mao YB, Xu YH, Jiang WH, Chen XY (2004) VdNEP, an elicitor from Verticillium dahliae, induces cotton plant wilting. Appl Environ Microbiol 70:4989-4995

Wang B, Yang X, Zeng H, Liu H, Zhou T, Tan B, Yuan J, Guo L, Qiu D (2012) The purification and characterization of a novel hypersensitive-like responseinducing elicitor from Verticillium dahliae that induces resistance responses in tobacco. Appl Microbiol Biotechnol 93:191-201

Wang N, Liu M, Guo L, Yang X, Qiu D (2016) A novel protein elicitor (PeBA1) from Bacillus amyloliquefaciens NC6 induces systemic resistance in tobacco. Int J Biol Sci 12:757-767

Wei ZM, Laby RJ, Zumoff CH, Bauer DW, He SY, Collmer A, Beer SV (1992) Harpin, elicitor of the hypersensitive response produced by the plant pathogen Erwinia amylovora. Science 257:85-88

Wilkins MR, Gasteiger E, Bairoch A, Sanchez JC, Williams KL, Appel RD, Hochstrasser DF (1999) Protein identification and analysis tools in the ExPASy server. Methods Mol Biol 112:531-552

Yang YX, Ahammed GJ, Wu C, Fan SY, Zhou YH (2015) Crosstalk among jasmonate, salicylate and ethylene signaling pathways in plant disease and immune responses. Curr Protein Pept Sci 16:450-461

Yano A, Suzuki K, Uchimiya H, Shinshi H (1998) Induction of hypersensitive cell death by a fungal protein in cultures of tobacco cells. Mol Plant Microbe Interact 11:115-123

Zhang Y, Yang X, Liu Q, Qiu D, Zhang Y, Zeng H, Yuan J, Mao J (2010) Purification of novel protein elicitor from Botrytis cinerea that induces disease resistance and drought tolerance in plants. Microbiol Res 165:142-151

Zhang Y, Yan X, Guo H, Zhao F, Huang L (2018) A novel protein elicitor BAR11 from Saccharothrix yanglingensis Hhs.015 improves plant resistance to pathogens and interacts with catalases as targets. Front Microbiol 9:700

\section{Publisher's Note}

Springer Nature remains neutral with regard to jurisdictional claims in published maps and institutional affiliations.

\section{Submit your manuscript to a SpringerOpen ${ }^{\circ}$ journal and benefit from:}

- Convenient online submission

- Rigorous peer review

- Open access: articles freely available online

- High visibility within the field

Retaining the copyright to your article

Submit your next manuscript at $>$ springeropen.com 